\title{
Analytical Results of Cam Ranh-Tuy Phong Fault Characteristics and Its Relation to Mud Eruption in Nam Trung Bo Area, Viet Nam
}

\author{
Truong Thanh Phi ${ }^{1}$, Van Thom Bui ${ }^{2}$ and Dang Manh Nguyen ${ }^{2}$ \\ 1. Hanoi University of Natural Resources and Environment, Hanoi, Vietnam \\ 2. Institute of Geology, Viet Nam Academy of Science and Technology, Hanoi, Vietnam
}

\begin{abstract}
By analyzing the satellite images, topology map, geology map, geomorphology map, and field survey data, this study has determined the Cam Ranh-Tuy Phong fault in the South Central area, Viet Nam has NE-SW orientation and inclines to SE with high slope angle of $70-80^{\circ}$. During the Pliocene-Quaternary period, the Cam Ranh-Tuy Phong fault is left-lateral movement with the extension mechanisms, which formed the graben have an NE-SW orientation, deposited by Quaternary sediment. The fracture systems and fault are the channels for the mineral water and hot water to move up from the deep zone in the area of Cam Thinh Dong, Ha Nhi, Vinh Hao, Nha Me, Tuy Thinh..., and also to be the channels for the mud material, clay and underground water to move from below zone to the surface to form high mud mounds. The analytical results of clay mud have identified clay mineral composition to be main montmorilonit, illite, kaolinite, calcite, chlorite. The occurrence of montmorilonit minerals in this study area is characterized by the alkali-rich environment. The chemical composition of calcite is determined forming in the environment of with $\mathrm{pH}>9$, characterized by the arid climates. Besides, other analytical results of clay mud also identified some minerals, such as: ankerite $(\mathrm{Fe}, \mathrm{Mg}) \mathrm{CO}_{3}$, calcite and some accessory minerals such as: fluorite, lepidocrokit with the participation hydrothermal process.
\end{abstract}

Key words: Fault zones, mud eruption, tectonic activities, mineral water, hot water.

\section{Introduction}

The neotectonic activity studies in the Nam Trung Bo area in Viet Nam, from Khanh Hoa to Binh Thuan have been concerned by Refs. [1, 2]. The studied results have identified major fault zones: Thuan Hai-Minh Hai and Nha Trang-Tanh Linh and several other smaller fault zones.

Recently, the eruption phenomenon of mud has occurred widely along the two fault zones: Thuan Hai-Minh Hai and Nha Trang-Tanh Linh. In 2011, the eruption mud formed mud mounds with the size of 20-30 m diameter and $1.5 \mathrm{~m}$ high in the areas: Nhi Ha, Ninh Thuan province, Cam Thinh Dong, Cam Ranh, Khanh Hoa province and Vinh Hao, Nha Me, Binh Thuan province.

Corresponding author: Truong Thanh Phi, Ph.D., research fields: structural geology, tectonic and geodynamics, geohazards, slope stability.
The occurred cause of this phenomenon has many different points of views. Some Vietnamese geologists said that the cause of the mud eruption phenomenon is not related to mud volcano activity and the other ideas suggested that the cause of the mud eruption on the land and seabed is caused by deep pressure, pushed gas, liquid and mud to go up along the young fault zones or the intersection of Song Ba-Nha Trang River fault zone and Bien Hoa-Tuy Hoa fault zone in the study area.

The analyzing field of the characteristics of mud eruption and their relation to fault systems in the Nam Trung Bo Viet Nam, within the coordinates of $108^{\circ} 22^{\prime} 44^{\prime \prime}-109^{\circ} 26^{\prime} 1.25^{\prime \prime} \quad \mathrm{E}$ and $11^{\circ} 1^{\prime} 53.24^{\prime \prime}$ $12^{\circ} 4^{\prime} 31.57^{\prime \prime} \mathrm{N}$ (Fig. 1), we indicated that the mud eruption activities in this area are caused by the tectonic activities of the Cam Ranh-Tuy Phong fault. 

Its Relation to Mud Eruption in Nam Trung Bo Area, Viet Nam

\section{Material and Methods}

\subsection{Material}

Remote sensing image Landsat 8 (2016) and topographic map of $1 / 50,000$ scale.

Collection data of structural geology and drilling support for this study, included: 21 survey sites in the field for analyzing structural geology and 09 boreholes to get samples of mineral water and hot water in the area of Nhi Ha and Loi Hai.

\subsection{Methods}

- Remote sensing method: to identify the lineaments and the distribution locations of mud eruption, mineral water and hot water;

- Structural geology analysis method: to determine the relationship between the distribution of mud eruption, mineral water, hot water and tectonic activities;

- Geo-chemical analysis method: to determine the chemical composition of clay mud, mineral water and hot water sample at each mud mound;

- Electrical measurement method: to determine the limitation of each mud mound.

\section{Results}

3.1 Characteristics of Cam Ranh-Tuy Phong Fault Zone

The Cam Ranh-Tuy Phong fault has NE-SW orientation, with over $100 \mathrm{~km}$ long, from Cam Loc, Cam Ranh, Kanh Hoa province to Tuy Phong, Binh Thuan province (Fig. 1).

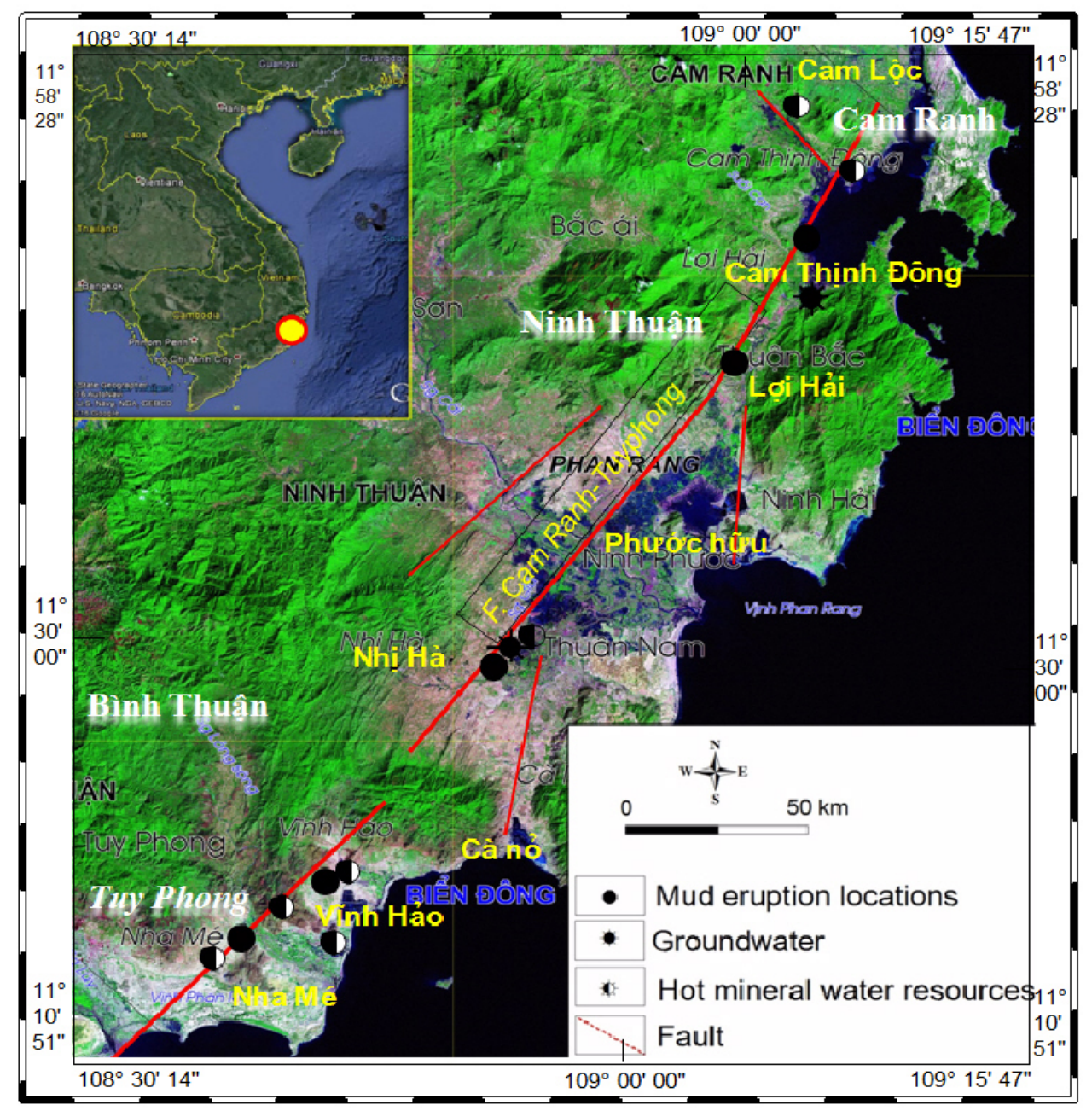

Fig. 1 Study area map and locations of mud eruption, ground water and hot mineral water. 
On the satellite images and topographic maps of $1 / 50,000$ scale, the fault zone is identified including several parallel and successive segments. The evidences identify the fault activities including:

- The existence of steep slopes in lines which were analyzed on the satellite images;

- The abrupt change between the geological formations on the geological cross section (between the bedrock and unconsolidated sediments);

- The sudden changes in the thickness of the Quaternary sediments on each cross section in the sedimentary basin;

- The movement of river and stream along two sides of the fault;

- The existence of fracture systems along fracture zone;

- The existence of the different structural geology stypes;

- The existence of the locations of the hot water and mineral water;

- The existence of outcrop groundwater locations;

- The existence of the slides on the fault surface;

- The changes of the sediment in the fracture zone;

- The existence of the mineral composition in mud samples: ankerite (Fe, $\mathrm{Mg}) \mathrm{CO}_{3}$, calcite, fluorite, lepidocrokit;

- The existence of geo-hazards to be due to tectonic activities along the fault zone;

- The existence of mud eruption locations along fault zone.

The analytical results have identified the characteristics of each fault segment as following:

The fault segment of Cam Loc-Thap Cham is in the NE-SW orientation, which coincided with the same direction of graben with $20 \mathrm{~km}$ long. The two slopes of graben are main granite rock and its bottom is deposited by sediment of alluvi, proluvi and river with the thickness varies between 1-6 m (Figs. 2 and 3).

The fault segment of Phuoc Huu-Nhi Ha is in the NE-SW orientation, which coincided with the same direction of graben, with $15 \mathrm{~km}$ long. The two sides of graben are low hills and their component is intrusive granitic rocks. The bottom of graben is deposited by sediment of alluvi, proluvi with the thickness varying between 0.2-6.0 m (Fig. 4).

The fault segment of Tuy Thinh-Hoa Thang is in the NE-SW orientation, which coincided with the same direction of graben, with $40 \mathrm{~km}$ long and $2 \mathrm{~km}$ wide. The two slopes of graben are main tuffaceous sandstone and its bottom is deposited by Quaternary sediment with the thickness varies between 5-10 m (Fig. 5).

In the Nhi Ha area, this fault zone has many evidences of sinistral movement (Fig. 6).

Along the fault, the rocks have been heavily broken, created the zone with $0.5-1.5 \mathrm{~m}$ wide, such as Vinh Hao area (Figs. 7a and 7b) and many fault surfaces exist clearly slikenside in the area of Phuoc Khang, Nhi Ha, Nha Me (Figs. 9a and 9b).
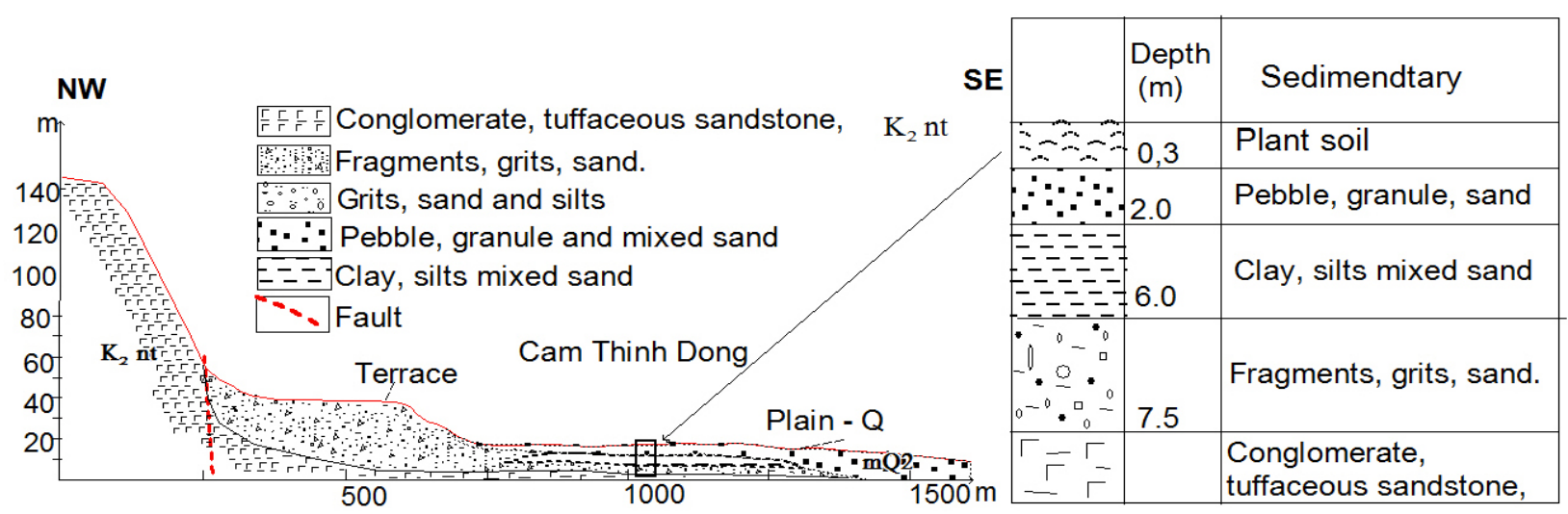

Fig. 2 Geological cross section in Cam Thinh Dong area.

(NW: $109.0914019^{0}, 11.86568250^{\circ}$ and SE: $109.1097546^{0}, 11.86811998^{\circ}$ ). 

Its Relation to Mud Eruption in Nam Trung Bo Area, Viet Nam

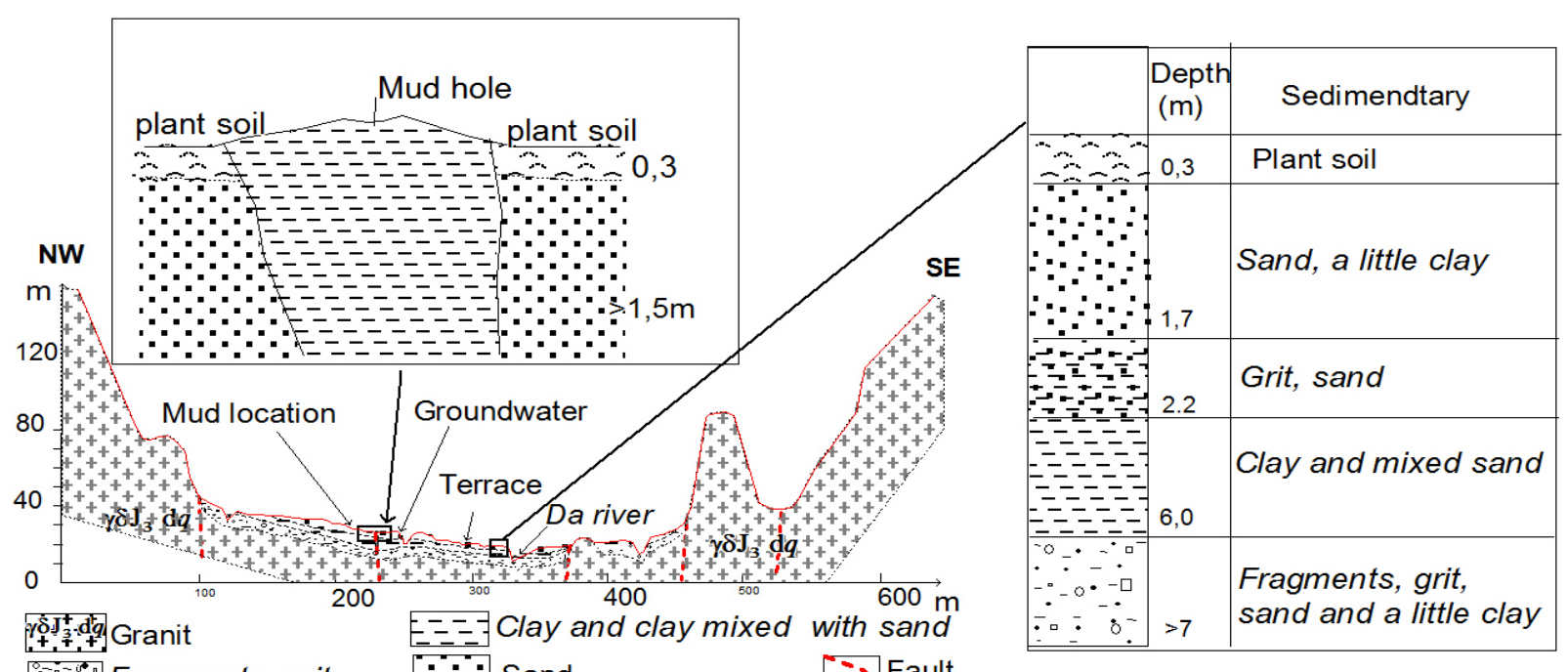

Fig. 3 Geological cross section in Loi Hai area.

(NW: $109.0532058^{0}, 11.76148352^{\circ}$ and SE: $109.0779196^{0}, 11.77285280^{\circ}$ ).

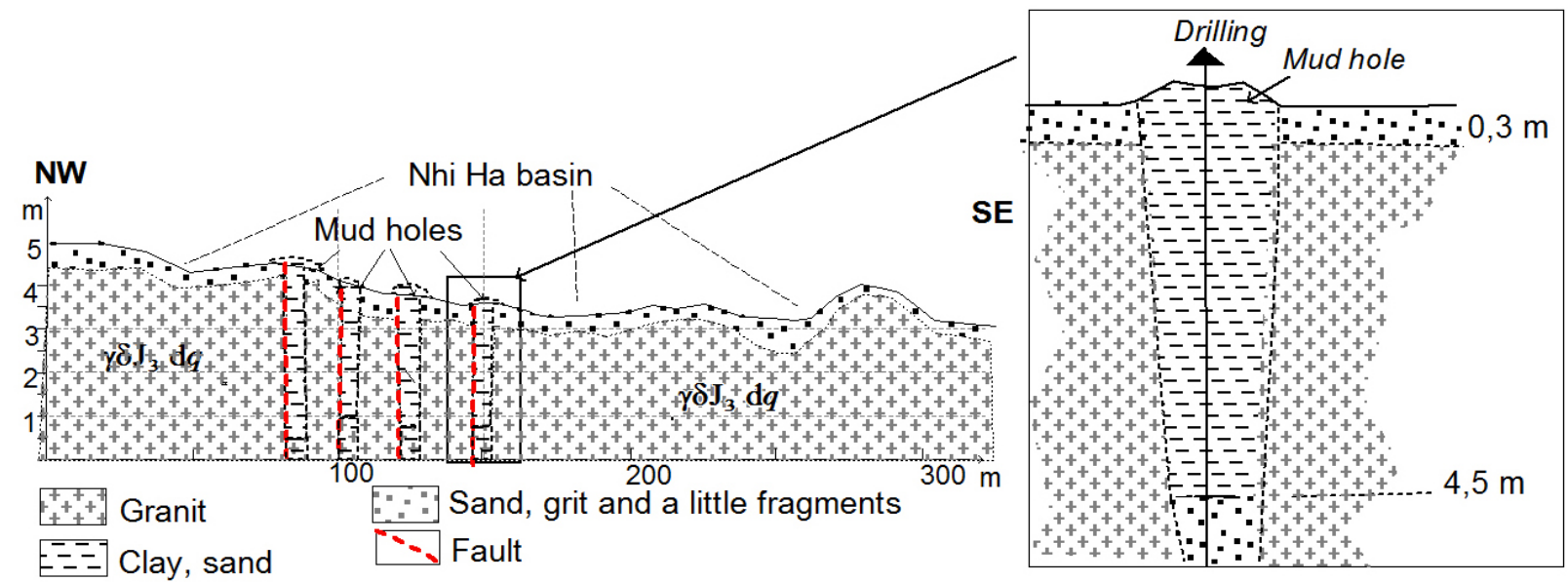

Fig. 4 Geological cross section in Nhi Ha area.

(NW: $108.8127947^{0}, 11.44837077^{\circ}$ and SE: $108.8408092^{\circ}, 11.45798254^{\circ}$ ).

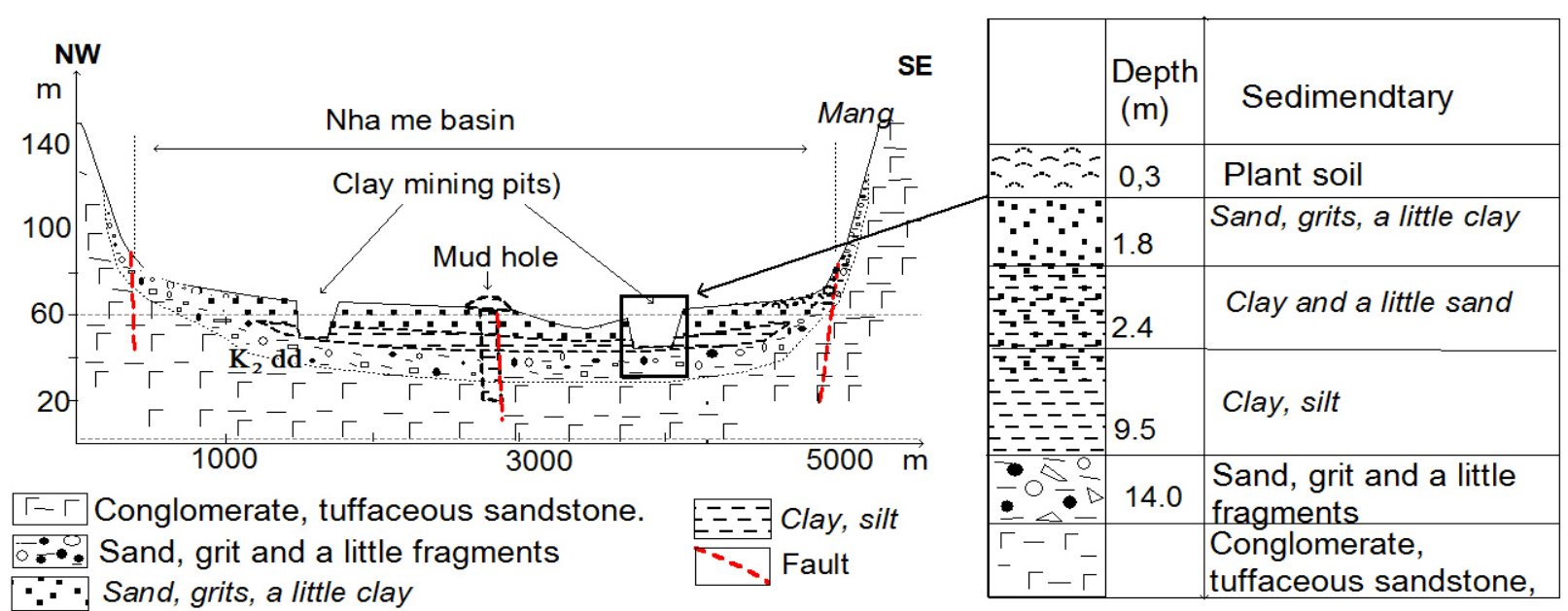

Fig. 5 Geological cross section in Nha Me area.

(NW: $108.6630806^{0}, 11.24187270^{\circ}$ and SE: $108.6196866^{\circ}, 11.26605378^{\circ}$ ). 

Its Relation to Mud Eruption in Nam Trung Bo Area, Viet Nam

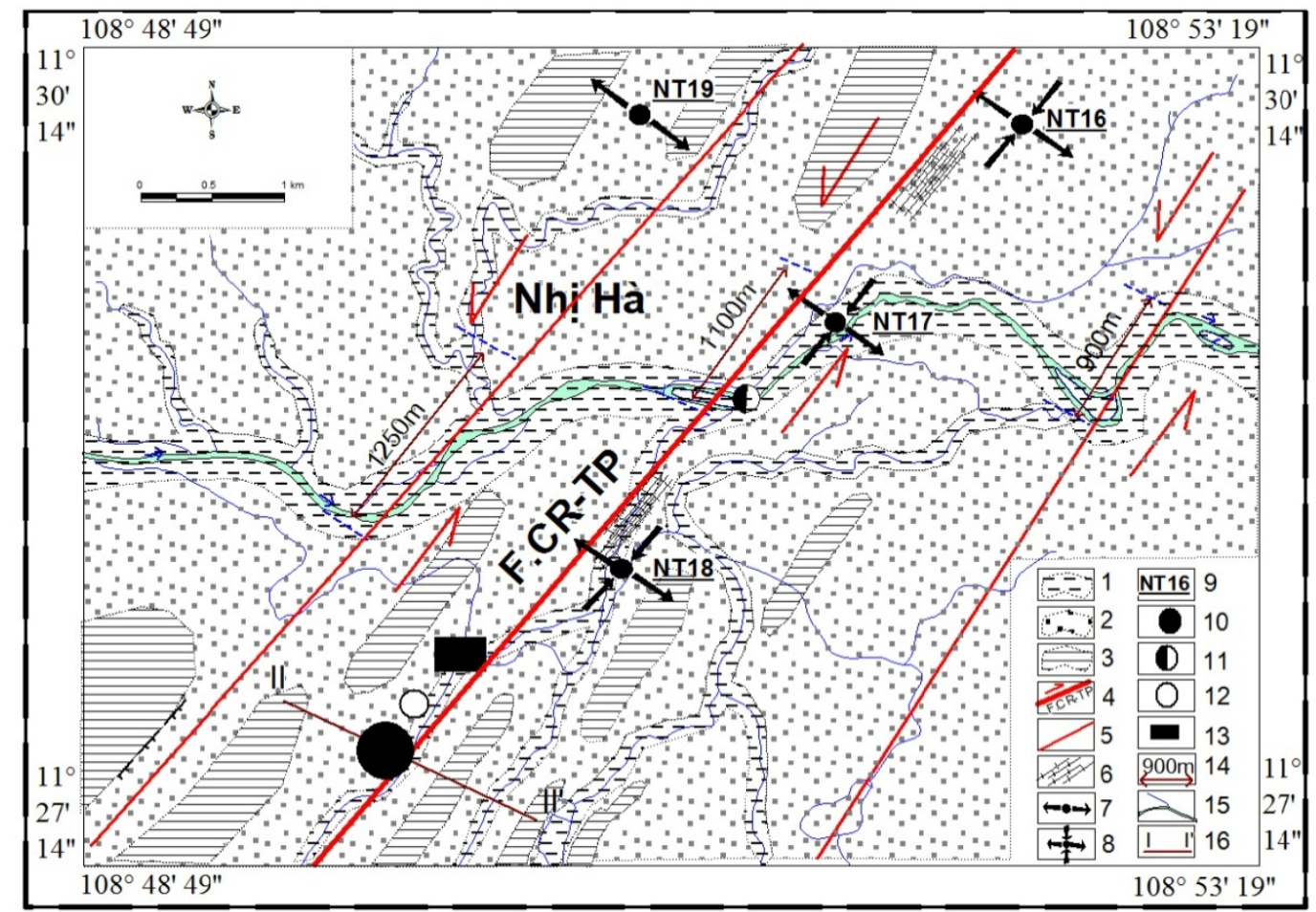

Fig. 6 Left lateral strike slip fault in Nhi Ha area.

(1. Sand, clay- alluvi; 2. Sand, grits-Proluvi; 3. Granite stone; 4. Main fault; 5. Sub-fault; 6. Broken zone; 7. Stresses rift; 8. Lateral stresses; 9. Measuring point; 10. Mud eruption locations; 11. Hot mineral water; 12. Groundwater; 13. Land subsidence. 14. Displacement distance. 15. River; 16. Profile)
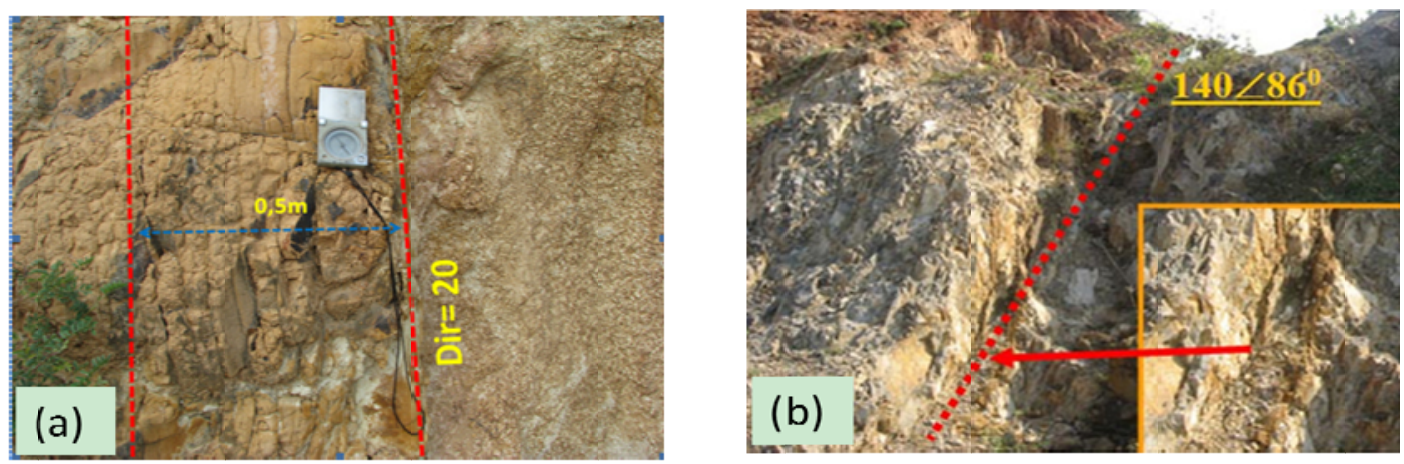

Fig. 7 (a) Fracture zone in the weathering layer from granite rock in Phuoc Khang area; (b) Fracture zone with much loam and clay in the Phuoc Khang area.
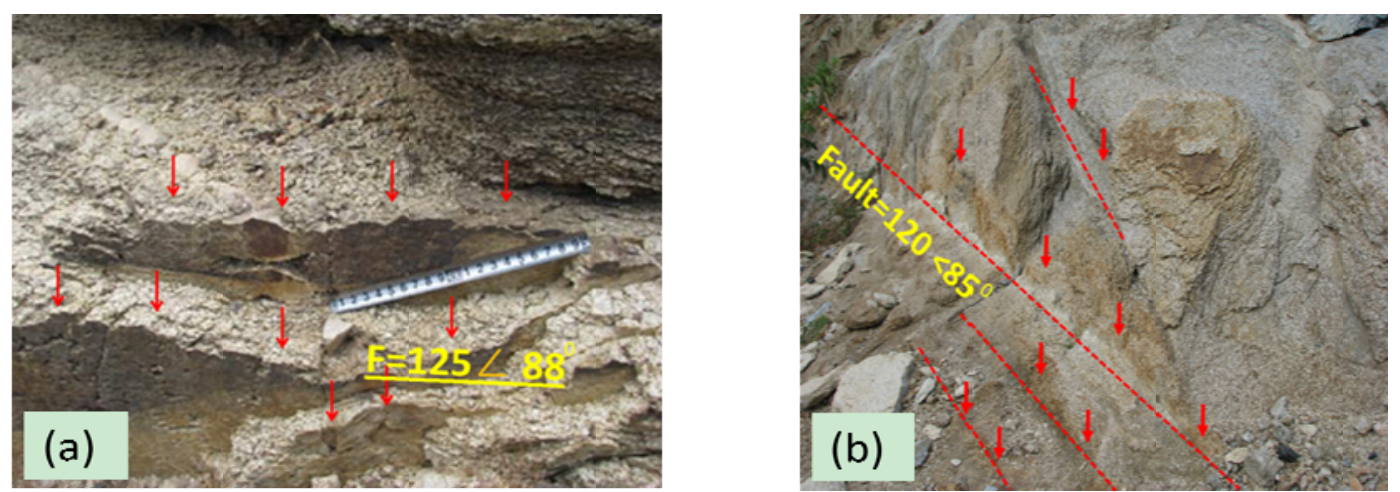

Fig. 8 Fault surface and slickenside in the weathering Granite zone. 

Its Relation to Mud Eruption in Nam Trung Bo Area, Viet Nam

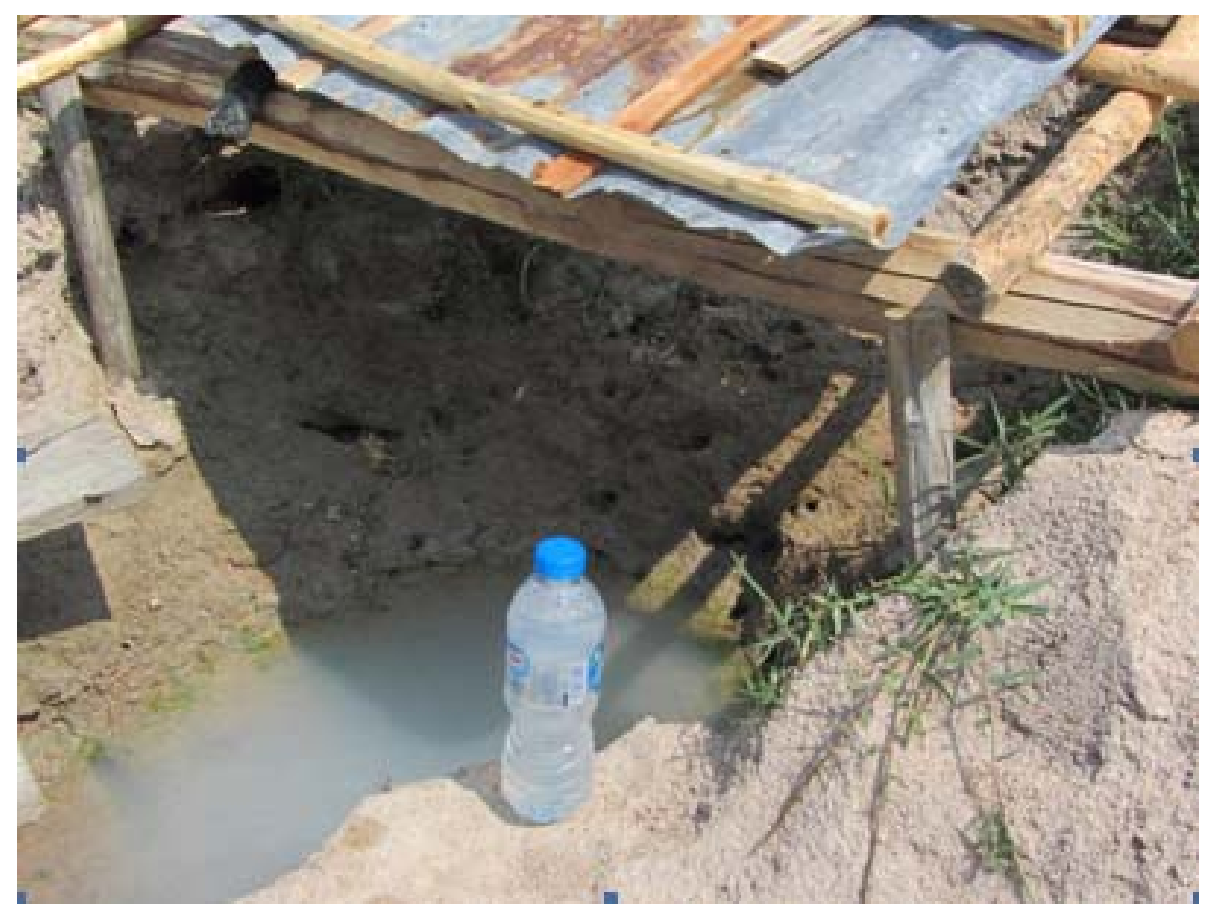

Fig. 9 Hot mineral water outcrop location in Loi Hai area.

Table 1 Stress field along Cam Ranh-Tuy Phong fault zone in Pliocen-Quaternary period.

\begin{tabular}{|c|c|c|c|c|c|c|}
\hline No & $\begin{array}{l}\text { Longitude } \\
\text { (degree) }\end{array}$ & $\begin{array}{l}\text { Latitude } \\
\text { (degree) }\end{array}$ & $\begin{array}{l}\sigma_{1} \\
\text { (degree) }\end{array}$ & $\begin{array}{l}\sigma_{2} \\
\text { (degree) }\end{array}$ & $\begin{array}{l}\sigma_{3} \\
\text { (degree) }\end{array}$ & Descriptions \\
\hline NT-01 & 109.089 & 11.8505 & $250<00$ & $070<88$ & $160<00$ & Strike slip fault \\
\hline NT-02 & 109.051 & 11.8378 & $305<03$ & $035<15$ & $206<74$ & Normal fault \\
\hline NT-03 & 109.046 & 11.8352 & $254<17$ & $001<43$ & $148<42$ & Normal fault \\
\hline NT-04 & 109.039 & 11.8352 & $282<00$ & $012<65$ & $192<25$ & Normal fault \\
\hline NT-05 & 109.063 & 11.8057 & $305<03$ & $115<26$ & $354<46$ & Normal fault \\
\hline NT-06 & 109.068 & 11.7946 & $289<03$ & $023<56$ & $197<34$ & Normal fault \\
\hline NT-07 & 109.098 & 11.7935 & $279<06$ & $179<61$ & $012<28$ & Normal fault \\
\hline NT-08 & 109.081 & 11.7708 & $102<19$ & $351<47$ & $207<37$ & Normal fault \\
\hline NT-09 & 109.072 & 11.7469 & $100<11$ & $280<79$ & $010<02$ & Strike slip fault \\
\hline NT-11 & 109.062 & 11.6988 & $260<00$ & $170<71$ & $350<19$ & Strike slip fault \\
\hline NT-13 & 109.054 & 11.7716 & $292<00$ & $202<60$ & $002<30$ & Normal fault \\
\hline NT-16 & 108.815 & 11.4899 & $315<00$ & $135<88$ & $225<00$ & Strike slip fault \\
\hline NT-17 & 108.868 & 11.4979 & $091<26$ & $237<59$ & $353<15$ & Strike slip fault \\
\hline NT-19 & 108.856 & 11.4831 & $290<06$ & $050<78$ & $199<10$ & Strike slip fault \\
\hline NT-30 & 108.704 & 11.3001 & $115<10$ & $220<54$ & $018<34$ & Normal fault \\
\hline NT-22 & 108.659 & 11.3112 & $234<34$ & $126<25$ & $007<45$ & Normal fault \\
\hline NT-23 & 108.659 & 11.2979 & $285<16$ & $053<65$ & $190<19$ & Strike slip fault \\
\hline NT-25 & 108.665 & 11.2596 & $105<10$ & $198<13$ & $339<73$ & Normal fault \\
\hline NT-26 & 108.680 & 11.2474 & $305<00$ & $035<67$ & $215<23$ & Strike slip fault \\
\hline NT-27 & 108.701 & 11.2249 & $275<10$ & $020<54$ & $178<74$ & Normal fault \\
\hline NT-29 & 108.659 & 11.324 & $115<05$ & $220<70$ & $023<19$ & Strike slip fault \\
\hline NT-28 & 108.721 & 11.2536 & $289<21$ & $055<56$ & $189<24$ & Strike slip fault \\
\hline NT-21 & 108.731 & 11.2739 & $121<17$ & $269<70$ & $028<10$ & Strike slip fault \\
\hline
\end{tabular}

The analytical results of structural geology along the Cam Ranh-Tuy Phong fault zone are conducted by using the program Faultkin 7 of Allmendinger R. W. (Table 1). 
The above analytical results indicated that the Cam Ranh-Tuy Phong fault is active in Pliocen-Quaternary period, according to extension mechanism, created favorable conditions for mineral water, hot water, mud eruption, landslide development.

On each segment of Cam Ranh-Tuy Phong fault, there are many locations of hot mineral water, such as: Ba Ngoi, Nhi Ha, Loi Hai, Vinh Hao, Chau Cat, Tuy Thinh and Nha Me... (Fig. 1). The hot mineral water in this area is determined as sodium bicarbonate mineral water category. Currently, some of the locations are being exploited to bottle or server for shower water services and treatment.

\subsection{Characteristics of Mud Eruption Locations}

The analytical results of fault characteristics and mud eruption in the study area have identified that they have a close relationship with each other. The mud and clay are erupted on the surface along fracture systems and fault. There are five mud eruption locations: Cam Thinh Dong, Loi Hai, Nhi Ha, Vinh Hao and Nha Me, created the band according to NE-SW orientation, from Cam Ranh to Binh Thuan, coincided with Cam Ranh-Tuy Phong fault zone (Fig. 1). Each eruption location has several mud mounds with the different sizes of approximately $15-20 \mathrm{~m}$ in length, $1.5-2 \mathrm{~m}$ in width and $1.5-2 \mathrm{~m}$ in height within graben of the same direction of Cam Ranh-Tuy Phong fault orientation (Fig. 10).

The drilling results obtained at different several locations showed that the composition of the clay material in the samples contains the minerals of montmorilonit, content of $15-25 \%$ in Nhi Ha and Loi Hai area and $70-75 \%$ in the Nha Me area.

The analytical results of the chemical composition in mineral water and hot water within the study area have determined that they belong to the type of silic-Flour including sodium bicarbonate with medium and low mineralization.

The analytical results of the mineral composition in the clay mud have obtained mainly montmorilonit, illite, kaolinite, calcite, chlorite. The presence of montmorilonit mineral reflects the rich alkaline environment. Besides, the chemical composition of calcite which was created in an environment with $\mathrm{pH}>$ 9, reflecting the arid climate environment.

Based on the geological characteristics, the type of clay in this area is assumed, forming in the weathering zone of bedrock with rich alkaline minerals. Besides, in the mineral composition of the clay also has some

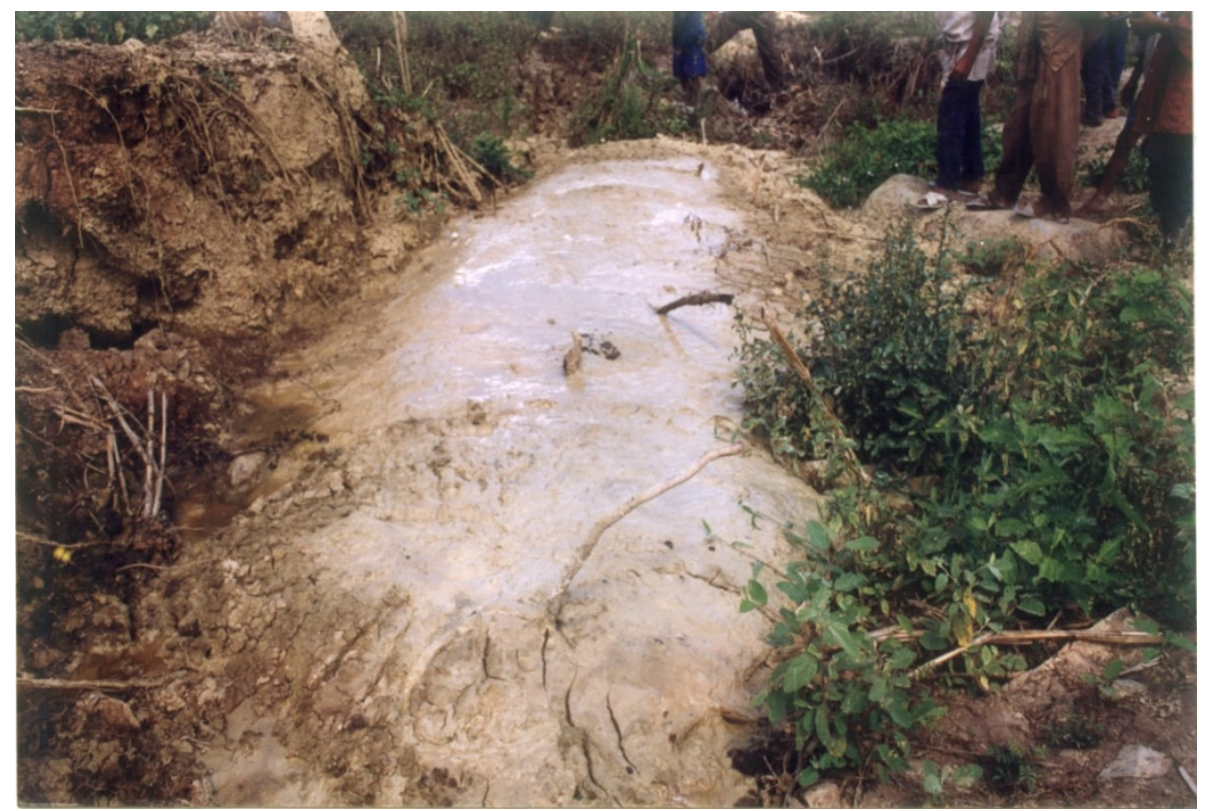

Fig. 10 Mud mound is erupted along the Cam Ranh-Tuy Phong fault in Nhi Ha with about 10-15 $\mathrm{m}$ in length and 2-3 $\mathrm{m}$ in width. 
Table 2 Mineral composition at clay level $<0.063 \mathrm{~mm}$ at the mud eruption location, Suoi Da village, Loi Hai commune, Thuan Bac district.

\begin{tabular}{llll}
\hline \multirow{2}{*}{ No. } & Minerals & \multicolumn{2}{c}{ Mineral composition at clay level $<0.063 \mathrm{~mm}$} \\
\cline { 3 - 4 } & MLH01 & BLH02 \\
\hline 1 & Montmorilonit & $30-40$ & $25-30$ \\
3 & Ilit & 15 & 12 \\
4 & Kaolinit & $5-10$ & $10-15$ \\
5 & Clorit & $4-5$ & 5 \\
6 & Felspat & $4-5$ & $10-15$ \\
7 & Quartz & $10-15$ & $5-8$ \\
8 & Hydroxide $\mathrm{Fe}$ & $6-8$ & $4-5$ \\
9 & CaCO & 4 & 5 \\
\hline
\end{tabular}

Table 3 Mineral composition at clay level $<0.063 \mathbf{~ m m}$ mud eruption location at Nhi Ha, Thuan Nam district.

\begin{tabular}{llll}
\hline \multirow{2}{*}{ No. } & Minerals & \multicolumn{2}{c}{ Mineral composition at clay level $<0.063 \mathrm{~mm}$} \\
\cline { 3 - 4 } & MNH01 & BNH02 \\
\hline 1 & Montmorilonit & $25-27$ & $20-30$ \\
2 & Ilit & $10-12$ & 12 \\
3 & Kaolinit & $13-15$ & $12-15$ \\
4 & Clorit & $4-6$ & 8 \\
5 & Felspat & $12-14$ & $10-12$ \\
6 & Quartz & $6-8$ & 6 \\
7 & Hydroxit Fe & $4-6$ & $2-4$ \\
8 & CaCO & $<10$ & $<10$ \\
9 & Ankerit $(\mathrm{Mg}, \mathrm{Fe}) \mathrm{CO}_{3}$ & $<7$ & 5 \\
10 & Fluorit & 5 & 7 \\
\hline
\end{tabular}

different minerals, such as: ankerite $(\mathrm{Fe}, \mathrm{Mg}) \mathrm{CO}_{3}$, calcite and some minerals: fluorite, lepidocrokit with the occurrence of hydrothermal processes (Tables 2 and 3).

\section{Discussions}

On the geological map (Fig. 11), the Cam Ranh-Tuy Phong fault zone cut through the granite rock, late Jurassic age belongs to Dinh Quan formation. In the field, the traces of slickenside and movement of calcite dyke are very clear.

The movement of faults formed the graben bands in NE-SW orientation, which is deposited by the unconsolidated Quaternary sediments. Along the fault zone, there are many fractures, landslides, hot mineral water outcrop, underground water and mud eruption to be the evidences to confirm that this fault is still active.

The studies of mud volcano activities have been concerned by geologists from many decades ago and they mainly concentrated in the seabed. The causes and mechanisms of mud volcanoes in the seabed are clearly explained in Refs. [3-6].

The results in their studies have said that the mud volcano activity is related to sedimentary basins, thickness, pressure, tectonic faults and fluids run along the fault zone. Chow et al. [7] showed the existence of fault zones around mud volcanoes.

In addition, the other studies also showed that the largest mud volcanoes in the world have over $10 \mathrm{~km}$ in diameter and nearly $700 \mathrm{~m}$ in height, such as: the Kazakov mud volcano has a diameter of $2.5 \mathrm{~km}$ and $120 \mathrm{~m}$ high [8].

The characteristic of mud volcano is the occurrence of sedimentary rocks, formed at the place where the mixtures of fine sediments in liquids, usually associated with rock debris or compacted mud, discharged on the surface of seabed [3, 9-11].

In the South Central area of Viet Nam, the sedimentary rocks are mainly from Jurassic to Cretaceous 


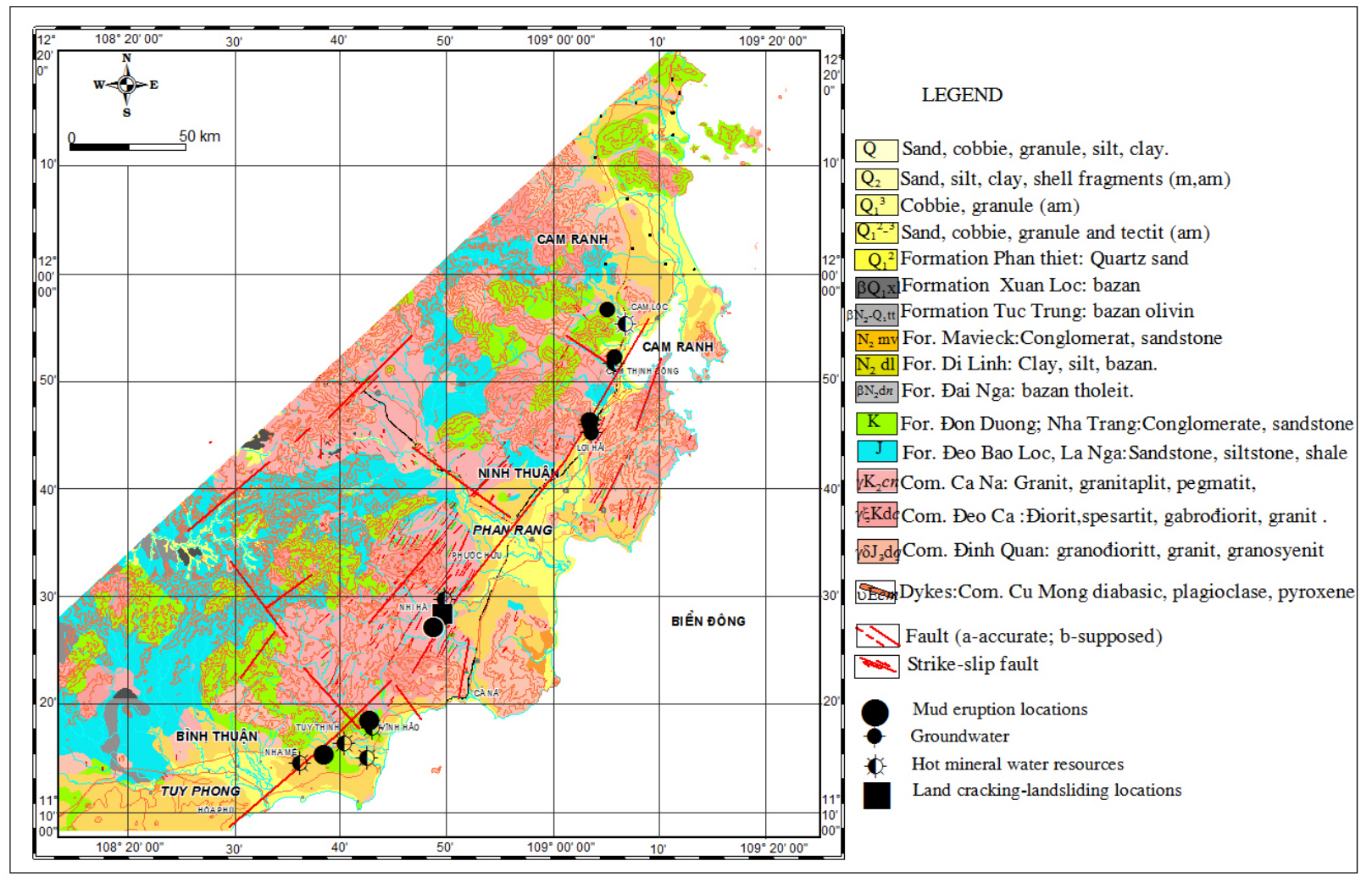

Fig. 11 Geological map of study area.

ages (Fig. 11). The mud eruption activities in here are determined to be related to Cam Ranh-Tuy Phong fault zone. However, these are only the initial results. These results need to be analyzed in detail and compared to the surrounding area to ensure accuracy.

\section{Conclusions}

The analytical results of satellite images, topology map, geology map, geomorphology map and field survey data, have determined that about the Cam Ranh-Tuy Phong fault in the South Central area, Viet Nam has NE-SW orientation, inclines to SE with high slope angle of 70-80 degrees.

During the Pliocene-Quaternary period, this fault is left-lateral movement with the extension mechanisms, which formed the graben have an NE-SW orientation, deposited by Quaternary sediments.

The fracture system and faults are the channels for the mineral water, hot water to move up from the deep zone in Cam Thinh Dong, Ha Nhi, Vinh Hao, Nha Me,
Tuy Thinh..., and also to be the channels for the mud material, clay and underground water to move from below zone to the surface to form the high mud mounds.

The analytical results of clay mud have identified clay mineral composition to be main montmorilonit, illite, kaolinite, calcite, chlorite. The occurrence of montmorilonit minerals in this study area is characterized by the alkali-rich environment. The chemical composition of calcite is determined forming in the environment of with $\mathrm{pH}>9$, characterized by arid climates.

Besides, other analytical results in clay mud also identified some minerals, such as: ankerite $(\mathrm{Fe}, \mathrm{Mg})$ $\mathrm{CO}_{3}$, calcite and some accessory minerals such as: fluorite, lepidocrokit with the participation hydrothermal process.

\section{Acknowledgements}

This paper is financially supported by the Project of 

Its Relation to Mud Eruption in Nam Trung Bo Area, Viet Nam

Vietnam Academy of Science and Technology (Code: VAST05.03/14-15).

\section{References}

[1] Nguyen Trong, Y., and Pham Van, H. 1996. "The Results of Studying Activity Mechanism of Tectonic Fault in Nam Trung Bo in Kainozoi Period.” Journal of Geology Series A: 47-58.

[2] Tran Van, T., Van Duc, T., and Nguyen Thi, T. H. 2006. "Characteristics of Tectonic Development in Da Lat Zone and Adjacence in Late Mesozoic and Kainozoi Period." Viet Nam Journal of Earth Science 2: 140-9.

[3] Barber, A. J., Tjokrosapoetro, S., and Charlton, T. R. 1986. "Mud Volcanoes, Shale Diapirs, Wrench Fault and Melanges in Accretionary Complexes, Eastern Indonesia." Bulletin of the American Association of Petroleum Geologists 70: 1729-41.

[4] Hedberg, H. D. 1974. "Relation of Methane Generation to Undercompacted Shales, Shale Diapirs, and Mud Volcanoes." AAPG Bulletin 58: 661-73.

[5] Hovland, M., and Judd, A. G. 1988. Seabed Pockmarks and Seepages: Impact on Geology, Biology and the
Marine Environment. London: Graham and Trotman.

[6] Yakubov, A., Ali-Zade, A., and Zeinalov, M. 1971. Mud Volcanoes of the Azerbaijan SSR: Atlas. Baku: Azerbaijan Academy of Sciences.

[7] Chow, J., Lee, J. S., Liu, C. S., Lee, B. D., and Watkins, J. S. 2001. "A Submarine Canyon as the Cause of a Mud Volcano-Liuchieuyu Island in Taiwan." Marine Geology 176: 55-63.

[8] Krastel, S., Spiess, V., Ivanov, M., Weinrebe, W., Bohrmann, G., Shashkin, P., and Heidersdorf, F. 2003. "Acoustic Investigations of Mud Volcanoes in the Sorokin Trough, Black Sea." Geo-Mar Lett 23: 230-8.

[9] Cita, M. B., Ryan, W. B. F., and Paggi, L. 1981. "Prometheus Mud Breccia. An Example of Shale Diapirism in the Western Mediterrranean Ridge." Annales Geologiques des Pays Helleniques 30: 543-69.

[10] Holland, C. W., Etiope, G., Milkov, A. V., Michelozzi, E., and Favali, P. 2003. "Mud Volcanoes Discovered Offshore Sicily.” Mar. Geol. 199: 1-6.

[11] Staffiniet, F., Spezzaferri, S., and Aghib, F. 1993. "Mud Diapirs of the Mediterranean Ridge: Sedimentological and Paleontological Study of the Mud Breccia." Rivista Italiana di Paleontologia e Stratigsafia 99 (2): 225-54. 